SIR,-May I comment on your leading article (17 May, p. 352) "A Criminal Approach to Abontion"?

As a general practitioner I do not agree that the provisions of the Abortion (Amendment) Bill represent a serious threat to the professional freedom of doctors. I support the view expressed by those who in the Lane Report, as quoted in the same article, see the present "Act and its workings as evidence of a serious and progressive decline in the standards of morality in sexual behaviour of this society." Surely we should seek to halt this decline and I believe the Abortion (Amendment) Bill would act as a brake in this connexion and at the same time relieve the pressure on the doctor who finds it well nigh impossible, under present conditions, to invoke the conscience clause. Many of the notorious abuses would be eliminated and I believe that the best interests of the woman would be served, the criteria being sufficient for compassionate and justifiable termination. Her best interests may not after all be served by those who clamour, as do your correspondents from the Students Union of the London Hospital (10 May, p. 337), for abortion virtually on demand. The Lane Report in this connexion is emphatic that the decision should not be left to the woman, for "to expect doctors to operate under ordens without reference to their judgement would be contrary to good medical practice and would $a^{1}$ so be to the disadvantage of their patients" (para. 190).-I I am, etc.,

Cardiff

MARGARET WILKINSON

\section{Mixed Connective Tissue Disease with} Digital Gangrene

SIR,-We were interested to read the account by Dr. D. Kitchener and others (1 February, p. 249) stressing the distinctive clinical features and good prognosis of patients with mixed connective tissue disease. This promps us to report a similar case.

The patient was a 29-year-old West Indian woman seen in March 1971 with a six months' history of severe Raynaud's phenomenon which was accompanied by sclerodactyly, finger tip gangrene, and necrosis. She had a transient arthritis, chest pain, and dyspnoea. The test for antinuclear factor (A.N.F.) was strongly positive but there were no L.E. cells. Eighteen months later she was admitted to King's College Hospital with a lupus-like rash on her face and chest. Serum creatinine phosphokinase activity was increased at $253 \mathrm{IU} / \mathrm{l}$. Pulmonary transfer factor was found to be $4.15 \mathrm{mmol} \mathrm{min}^{1} \mathrm{kPa}^{-1}(12 \cdot 4 \mathrm{ml} / \mathrm{min} / \mathrm{mm} \mathrm{Hg})$ (expected, $9.8 \mathrm{mmol} \mathrm{min}{ }^{-1} \mathrm{kPa}^{-1}(29.3 \mathrm{ml} / \mathrm{min} /$ $\mathrm{mm} \mathrm{Hg}$ )) with reduced lung volume. Serum creatinine, urea, and electrolytes, protein electrophoresis, immunoglobins, urine analysis, renal biopsy, and chest $x$-ray were all normal. Hand $x$ rays showed no calcinosis or erosions.

She improved dramatically on prednisolone $30 \mathrm{mg}$ daily but was readmitted in January 1973 with severe abdominal pain. At laparotomy the only abnormality found was a small amount of free fluid in the pelvis. In February 1975 her haemoglobin was $14.6 \mathrm{~g} / \mathrm{dl}$, E.S.R. $17 \mathrm{~mm}$ in $1 \mathrm{hr}$, A.N.F. 1:320, IgG 32 g/l, DNA-binding capacity $40 \%$. Her serum was run in double diffusion against calf thymus extractable nuclear antigen on two occasions with negative results. (We are grateful to Dr. M. L. Snaith for this investigation.)

As in the case reported by Dr. Kitchener and his colleagues, our patient's greatest problem was her severe Raynaud's phenomenon, which was associated with clinical features of sclerodactyly and ischaemic necrosis of the finger tips. She also had evidence of polymyositis and a pulmonary diffusion defect and had a severe attack of abdominal pain resulting in laparotomy. Her rash suggested systemic lupus erythematosus, but antibodies to DNA were not significantly raised and her C3 levels were normal. There was no evidence of renal involvement. We can confirm the dramatic response to steroid therapy, but would like to point out that our patient now has a negative extractable nuclear antigen test despite some continuing disease activity.-We are, etc.,

M. G. Molloy

E. B. D. HAMILTON

King's College Hospital,

London S.E.5

\section{Imported Sterile Water}

SIR,-With reference to the letter from $\mathrm{Mr}$. C. Shaldon (19 April, p. 142) concerning the high cost of sterile water, we have for many years been experts in the production of deionized water and would gladly consider the production of sterile material if the demand was likely to justify this.

Perhaps through the hospitality of your columns we could ask hospital pharmacists and other interested panties to write to us so that we can gauge whether such a production, at a much cheaper price than imported water, would be justified.-I am, etc.,

David MOREAU DAVID MOREAU
Managing Director,
Elga Products Ltd.

Lane End, Bucks Elga Products Lid.

Predictive Value of Hydroxyproline: Creatinine Ratio in Advanced Breast Cancer

SIR,-Dr. T. J. Powles and his colleagues (26 April, p. 164) felt that they could not comment on the predictive value of the hydroxyproline:creatinine ratio in patients with disseminated breast cancer. We have found the relationship to normal control values useful and now believe that the initial hydroxyproline:creatinine ratio can be of prognostic value in patients with metastatic bone involvement. Review at 16 months of 26 patients with radiological bone involvement previously reported ${ }^{1}$ revealed that 12 of 14 with an elevated ratio (above 2.88) had since died. On the other hand only one of 12 patients with a ratio below 2.88 had died.

In our study we commented that reversion of an elevated hydroxyproline: creatinine ratio to normal after treatment could be accompanied by objective radiological bone remission. So far three patients have shown reversion of the ratio to normal with radiological bone remission lasting longer than six months. One of these cases illustrates the danger of equating soft-tissue or visceral response to systemic treatment with its effect on bone disease. After adrenalectomy the hydroxyproline:creatinine ratio fell to normal and there followed bone sclerosis lasting more than six months. However, while the ratio was normal, clinically progressive hepatomegaly due to metastases became evident, followed by gross clinical and biochemical jaundice. Despite corticosteroids and quadruple chemotherapy the patient died still exhibiting signs of bony remission.
We would therefore advise caution in interpreting a fall in the hydroxyproline: creatinine ratio in disseminated breast cancer as reflecting anything other than the effect of treatment on bone disease, which can coexist with progression of local or visceral deposits.-We are, etc.,

J. G. ROBERTS M. BAUM

University Department of Surgery, Cardif

1 Roberts, J. G., et al., Clinical Oncology, 1975,
1,33.

\section{Droperidol for Emotional States in} Subnormal Patients

SIR,-The role of the hospital caring for the mentally handicapped is changing gradually in Britain. With a reduction in the number of patients being retained, far greater emphasis is being placed upon initiating regimens of treatment and admitting emotionally disturbed patients for limited periods of crisis. States of severe agitation are dealt with by tactful nursing supervision and, if necessary, the administration of a suitable quick-acting sedative. Outbursts of this nature may occur in subnormal patients who have superadded psychiatric illnesses, such as schizophrenia, oyclic affective disorders, autism, and psychopathic behaviour attributable to brain damage.

Drugs which control violent behaviour range from paraldehyde to the phenothiazines or butyrophenones-all have advantages and disadvantages. Droperidol belongs to the group of butyrophenone neuroleptics and is characterized by a very low order of acute toxicity. ${ }^{2}$ It is more rapidly absorbed than other neuroleptics of the same group, its action being both more rapid and of shorter duration. $\mathrm{Neff}^{3}$ has reported on its effects in a group of psychotically agitated patients. This drug has found its most useful role so far as a preanaesthetic sedative. ${ }^{4}$ It protects against the effects of traumatic shock, ${ }^{1}$ has an antiarrhythmic effect in inhibiting ventricular tachycardia and fibrillation induced by intravenous adrenaline, and an adrenolytic effect much less than that of ohlorpromazine. $^{5}$ For the past year we have used this compound as the drug of choice in the treatment of acute schizophrenic episodes, attacks of manic behaviour, the control of violent aggression in epileptic patients, and the sedation of severe emotional disturbances in autistic and brain-damaged patients. Given orally in $10-$ or $20-\mathrm{mg}$ doses the sedative effects become evident in about $30 \mathrm{~min}$ and last four hours. No dystonic symptoms have been observed when used thus on over 100 occasions. If the emergency is very acute an intramuscular preparation is available. In our experience droperidol has been superior in its sedative effects to paraldehyde, the phenothiazines, and haloperidol.-We are, etc.,

T. S. DAviES

Llanfrechfa Grange Hospital,

MARGARET WHITE

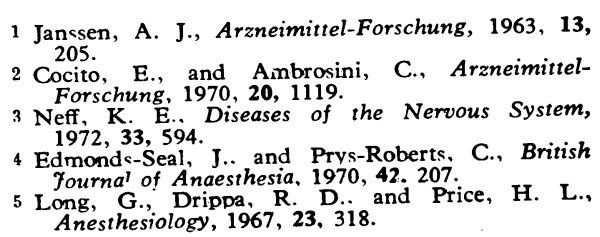

1 Janssen, A. J., Arzneimittel-Forschung, 1963, 13, 2 Cocito, E., and Ambrosini, C., ArzneimittelForschung, 1970, 20, 1119 1972, 33, 594. J.. and Prys-Roberts, C., British Fournal of Anaesthesia, 1970, 42. 207. Price, H. L., Anesthesiology, 1967, 23, 318 . 